\title{
Seisoenale patrone in die Suid-Afrikaanse kapitaalmark
}

\author{
F.S. Hattingh \& E v.d. M Smit* \\ Universiteit van Stellenbosch Bestuurskool, Posbus 610, Bellville 7535, Republiek van Suid-Afrika
}

Ontvang Februarie 1993, aanvaar Junie 1993

\begin{abstract}
Seasonal patterns in the South African capital market. In this article the seasonal patterns in daily price movements of the Post Office. Eskom 168 and the RSA bonds are examined and these are compared with three equity indices namely the Gold Index. Industrial Index and Overall Index of the Johannesburg Stock Exchange. Both the South African bond and share markets display significant seasonal patterns. In contrast with international findings, it is shown that seasonal similarities exist between the bond and share markets.

In dié artikel word seisoenale patrone in daaglikse prysbewegings van die Poskantoor-, Eskom 168-en die RSA-effekte ondersoek en sodanige patrone word met dié van drie aandele-indekse naamlik die Goudindeks, die Nywerheidsindeks en die Algehele Indeks van die Johannesburgse Effektebeurs vergelyk. Beide die Suid-Afrikaanse effekte- en aandelemarkte vertoon betekenisvolle seisoenale patrone. In teenstelling met intemasionale bevindings word aangetoon dat seisoenale ooreenkomste tussen die effekte- en aandelemarkte bestaan.
\end{abstract}

\section{Inleiding en literatuuroorsig}

Navorsing wat gemik is op die blootlegging van seisoenale patrone in kapitaalmarkte, is tipies van pogings om verhandelingsreèls bloot te lê wat dien om die effektiewe markhipotese te weerlê.

In Suid-Afrika het Bhana (1985) dic bestaan van 'n Maandag-effek aangetoon, terwyl Bradfield (1990) op die afwesigheid van 'n Januarie-effek gewys het. Op buitelandse kapitaalmarkte is daar egter in die onlangse verlede 'n verskeidenheid van seisoenale patrone blootgelê. Keim (1983, 1986) en Lakonishok \& Smid (1984) het aangetoon dat daar 'n Januarie-patroon bestaan in dic opbrengste van aandele as gevolg van abnormale hoë opbrengste in Januarie, waarvan $50 \%$ van die opbrengs in die ecrste vyf dae gesentreer is, die sogenaamde jaareinde-effek. Verder het Keim (1986) bevind dat opbrengste hoog is op 'n Vrydag en laag is op 'n Maandag, en dat opbrengste positief is gedurende die cerste helfte van die maand en negatief is in die tweede helfte. Hierdie bevinding word onderskryf deur Ariel (1987) wat aantoon dat andele positiewe opbrengste lewer aan die begin van die maand, wat begin met die laaste dag van die vorige maand en strck tot en met die helfte van dic maand, waarna negatiewe opbrengste in die tweede helfte van die maand getoon word.

Gibbons \& Hess (1981) het in hul ondersoek na die dagvan-die-week-effek bevind dat die opbrengste van aandele negatief is op ' $n$ Maandag. In ondersoeke na patrone van skatkiswissels is bevind dat ' $n$ ondergemiddelde opbrengs op 'n Maandag en 'n bogemiddelde opbrengs op Woensdag voorkom wat dui op 'n betekenisvolle dag-van-die-weekeffek. Rogalski (1984) sluit hierby aan en toon dat opbrengste op 'n Maandag positief is in Januarie, maar negatief is gedurende die res van die jaar en dat 'n groot deel van die dag-van-dic-week- en Januarie-cffek gesentreer is in die cerste vyf verhandclingsdac van die jaar. In 'n vergelykende studie het Jaffe \& Westerficld (1985) bevind dat daar in die VSA, Brittanje, Japan, Kanada en Australië ' $n$ naweek-effek bestaan, met ander woorde ' $n$ betekenisvolle verskil ussen 'n Maandag se sluitingsprys en ' $n$ Vrydag se sluitingsprys. In kontras met vorige Amerikaanse studies het hulle bevind dat die laagste gemiddelde opbrengs van aandele in Japan en Australië op 'n Dinsdag voorkom en nie op 'n Maandag nie.

Pettengill \& Jordan (1988) se bevindinge ondersteun vorige navorsing in sover die eerste paar verhandelingsdae van die jaar gekenmerk word deur abnormale hoc opbrengste. In 'n ondersoek na die verband tussen seisoenale patrone in opbrengste en die volume van verhandelbare effekte, is bevind dat naas die jaareinde en dag-van-die-week-effek, betekenisvolle seisoenale patrone ook bestaan in die opbrengste van maandeinde-dae - dit is die laaste dag van die vorige maand en die eerste drie dae van die nuwe maand en dat die patroon verantwoordelik is vir $50 \%$ van die maand se opbrengs. Die maandeinde-effek was ewe sterk vir groot en klein maatskappye, maar die jaareinde-effek en die Januarie-effek is nie betekenisvol vir groot maatskappye nie. Opbrengste van week drie was deurgaans negatief.

Jordan \& Jordan (1991) het ondersoek ingestel na seisoenale patrone in die daaglikse opbrengste van langtermyneffekte deur die gedragspatroon van die Dow Jones Composite Bond Average te ontleed en te vergelyk met twee aandelebeursindekse, naamlik die Standard en Poor 500 en 'n indeks saamgestel soos die Dow Jones Composite Bond Average. Hulle het aangetoon dat daar 'n betekenisvolle jaareinde-, week- en 'n Januarie-effek bestaan. Die opbrengste van die Standard en Poor 500 Indeks het 'n betckenisvolle dag-van-die-week- en maandeinde-effek getoon, maar die weekeffek was slegs betekenisvol by die $6 \%$ betekenispeil. Verder is bevind dat, met die uitsondering van die weekeffek, die langtermyneffekte-indekse'n spieëlbeeld van die Standard en Poor Indeks is, in sover waar hierdie indcks ' $n$ betekenisvolle patroon toon, die ander nie betekenisvol is nie.

Weinig navorsing is tot op datum in Suid-Afrika gedoen oor seisoenale patrone in die daaglikse opbrengste van langtermyneffekte en die ooreenkomste daarvan met die opbrengste van aandele. Gevolglik het hierdie studie ten doel om seisoenale patrone in die langtermyneffektemark te ondersoek, te beskryf en dit te vergelyk met die seisoenale patrone van Suid-Afrikaanse aandele-indekse, asook om vergelykings te tref met soortgelyke studies in ander lande. Die patrone wat ondersock is, is die: 
- dag-van-die weekeffek;

- weekeffek;

- maandeinde-effek;

- Januarie-effek;

- Januarie- versus ander nie-maandeinde-effek; en

- jaareinde- versus maandeinde-effek.

\section{Data en metodiek}

Die rou data wat in hierdie studie gebruik is, is verkry vanaf die databasis van Sanlam Beleggings. Dit bestaan uit daaglikse sluitingswaarnemings van ses indekse van die Johannesburgse Effektebeurs. Drie langtermyneffckte wat aktief verhandel naamlik die RSA-effek, die Eskom 168-effek en die Poskantoor-effek is gebruik. Die periodes waartydens data op 'n daaglikse basis beskikbaar was, is as volg:

RSA-effek:

1 Mei 1984 tot en met 3 Februarie 1992;

Eskom 168-effek: 1 Junie 1986 tot en met 3 Februarie 1992; en

Poskantoor-effek: 4 Januarie 1988 tot en met 3 Februanie 1992.

Indien ' $n$ sluitingskoers ontbreek of ' $n$ effek op ' $n$ bepaalde dag nie verhandel het nie, is die vorige beskikbare sluitingskoers gebruik.

Die daaglikse opbrengs per effek is bereken in ooreenstemming met die metode van Jordan \& Jordan (1991):

$\mathrm{R}_{\mathrm{t}}=\left(\mathrm{Bl}_{\mathrm{t}}-\mathrm{Bl}_{\mathrm{t}-1}\right) / \mathrm{BI} \mathrm{I}_{\mathrm{t}-1}$

waar:

$\mathbf{R}_{\mathbf{t}} \quad$ = die opbrengs van die effek vir dag $\mathbf{t}$;

$\mathrm{Bl}_{\mathrm{t}}$ = waarde van indeks aan einde van dag $\mathrm{t}$; en

$\mathrm{Bl}_{\mathrm{t}-\mathrm{l}}=$ waarde van indeks aan einde van dag $\mathrm{t}-\mathbf{l}$.

Jordan \& Jordan het die daaglikse sluitingspryse as waarnemings gebruik. Vir die doeleindes van hierdie studie is die daaglikse sluitingskoerse gebnuik, maar die resultate kan (op dieselfde manier as in die studie van Jordan \& Jordan, 1991) geïnterpreteer word deur slegs die teken van die berekende daaglikse opbrengste te verander, met ander woorde, 'n negatief berekende opbrengs waar sluitingskoerse gebruik word, is analoog aan 'n positiewe opbrengs sou sluitingspryse gebruik word.

Drie indckse van die aandelebeurs is gebruik, naamlik die Goudindeks, die Nywerheidsindeks en die Algehełe Indeks van die Johannesburgse Effektebeurs. Daaglikse sluitingspryse is gebruik in die berekening van die periode 2 Oktober 1978 tot en met 17 Januarie 1992. Daaglikse opbrengste is op dieselfde wyse as in die geval van effekte bereken.

Die data vir dag-van-die-week- en Januarie-effek is direk per dag of maand verdeel. Om die weekeffek te ondersoek, is die eerste tien handelsdae van die maand geklassifiseer as dae $+1,+2, \ldots,+10$ en die laaste tien handeisdae as dae -10 , $-9, \ldots,-1$. Die eerste 'week' van die maand bestaan dus uit dae +1 tot +5 , die tweede 'weck' uit dae +6 tot +10 , die derde uit dae -10 tot -6 en die laaste uit -5 tot -1 . Hierdie klassifiseringsmetode van 'weck' van die maand het tot gevolg dat slegs twintig waarnemings per maand in ag gencem kan word en dat alle ander dae, meer as twintig, geïgnoreer word. In gevalle waar maande oor minder as twintig dae beskik, is dae dubbeld getel. Die aanpassing is egter slegs van toepassing op toetse wat die weekeffek bepaal. In alle ander statistiese ontledings is daaglikse opbrengste slegs een keer gebruik.

Die maandeinde-effek word gedefinieer as die eerste vier verhandelingsdae in elke maand plus die laaste dag van die vorige maand. Om die effek te ondersoek, is die laaste dag van die vorige maand as -1 en die eerste vier dae van elke maand as dag $+1,+2,+3$ en +4 aangedui.

In navolging van Jordan \& Jordan (1991) is seisoenale patrone ontleed binne 'n eenrigtinganalise van variansieraamwerk, aangevul deur die Kruskal-Wallis-toets. In alle gevalle is beide die F-waarde en die Kruskal-Wallis-waarde bereken. Waar gestandaardiseerde maatstawwe van simmetrie en kurtose twyfel gewerp het op die normaliteitsaannames onderliggend tot die F-toets, is eerder op die KruskalWallis-toets gesteun. In die oorgrote meerderheid van gevalle, dui beide toetse by die $5 \%$ betckenispeil egter op dieselfde resultaat. Verwerking het geskied met behulp van die Statgraphics 5.0 rekenaarpakket.

\section{Resultate}

Die nulhipotese van geen betckenisvolle effek is getoets by wyse van 36 eenrigtinganalises van variansie (ses effekte is ondersock ten opsigte van elk van die ses finansiële instrumente). Die resultate is volledig gedokumenteer in Hattingh (1992), dit is gemiddeldes, mediane, standaardafwykings, maatstawwe van skeefheid en kurtose en die pwaardes van die parametriese en nie-parametriese toetsprosedures. Weens 'n gebrek aan ruimte word die tabulerings nie alhier volledig herhaal nie. In Tabel 1 word wel 'n opsomming van hicrdic resultate gegee. Die hoogste en laagste opbrengste word gerapporteer ten opsigte van elk van die patrone wat ondersoek is en daar word aangedui waar sodanige patrone betekenisvol is (by die 5\% betekenispeil).

\section{Dag-van-die-week-effek}

Die langtermyneffckte toon sonder uitsondering die hoogste opbrengs op ' $n$ Vrydag en die laagste opbrengs op 'n Maandag aan. Jordan \& Jordan (1991) het bevind dat dic Dow Jones Composite Bond Average 'n hoogste opbrengs op 'n Donderdag het en 'n laagste opbrengs op 'n Dinsdag het. Die Eskom 168- en RSA-effek toon beide 'n betekenisvolle dag-van-die-week-effek en die Poskantoor-effek volg dieselfde patroon, maar is nie betekenisvol nie. Jordan \& Jordan (1991) kon nie betekenisvolle dag-van-die-week-effekte in langtermyneffekte waameem nie.

In teenstelling met die langtermyneffekte, het die aandelebeurs-indekse 'n hoogste opbrengs op Woensdag (die opbrengs van die Nywerheidsindeks op Donderdag is ongeveer 0.3 basispunte hoër as die opbrengs op Woensdag) en 'n laagste opbrengs op Maandag. Maandag is die enigste dag met konsekwente negatiewe opbrengste. Die Nywerheidsindeks en Algchele Indcks toon 'n betekenisvolle dagvan-die-week-effck terwyl die Goudindeks betekenisvol is by die $7.69 \%$ betekenispeil. Die patroon van die beursindekse is dieselfde as dié van die Jordan \& Jordan (1991) 
Tabel 1 Opsomming van resultate van seisoenale patrone per instrument

Effekte

\begin{tabular}{|c|c|c|c|c|c|c|c|c|c|c|c|c|}
\hline \multirow[b]{2}{*}{ Instrumente } & \multicolumn{2}{|c|}{ Dag-van-die-week } & \multicolumn{2}{|c|}{ Week } & \multicolumn{2}{|c|}{ Maandeinde } & \multicolumn{2}{|c|}{ Januarie } & \multicolumn{2}{|c|}{$\begin{array}{l}\text { Januarie versus } \\
\text { nie-maandeinde }\end{array}$} & \multicolumn{2}{|c|}{$\begin{array}{l}\text { Jaareinde versus } \\
\text { maandeinde }\end{array}$} \\
\hline & Hoog & Laag & Hoog & Laag & Hoog & Laag & Hoog & Lag & Hoog & Laag & Hoog & Lagg \\
\hline Poskanicor & Vrydag & Maandag & Weck 1 & Week 3 & Mnd-cind* & Ander & Desember & Februarie & Nie-maand & Januarie & Res & Jaareinde \\
\hline Eskom 168 & Vrydag* & Maandag & Week $4^{*}$ & Week 3 & Mnd-eind* & Ander & Julie & September & Nie-maand* & Januarie & Jaareinde & Res \\
\hline Goud & Woensdag & Maandag & Week 1 & Week 2 & Mnd-eind & Ander & Augustus & Februarie & Nie-maand & Januarie & Jaareinde & Res \\
\hline Nywerheid & Donderdag* & Maandag & Weck 1 & Week 3 & Mnd-eind & Ander & Februarie & Oktober & Nie-maand* & Januarie & Jaareinde* & Res \\
\hline Algehele & Woensdag* & Maandag & Weck 1 & Week 3 & Mnd-eind* & Ander & Augustus & Oktober & Nie-maand* & Januarie & Jaareinde* & Res \\
\hline
\end{tabular}

Hoog =hoogste opbrengs; Laag = laagste opbrengs; * = betekenisvol by $5 \%$ betekenispeil

studie en die negatiewe opbrengste op 'n Maandag bevestig die resultate van Bhana (1985).

Beide die langtermyneffekte en beursindekse het dus 'n laagste opbrengs op Maandag. Die beursindekse se opbrengste is baie meer volatiel as dié van langtermyneffekte. Die daaglikse standaardafwyking van die beursindekse is 198 tot 246 basispunte in die geval van die Goudindeks teenoor 48 tot 64 basispunte in die geval van die RSA-cffek.

\section{Weekeffek}

Die langtermyneffekte toon 'n hoogste opbrengs in Week 1 van die maand (die opbrengs van die Eskom 168-effek in Week 4 is hör as in Wcek 1) met Week 4 wat ook positiewe opbrengste toon. Weke 2 en 3 vertoon negatiewe opbrengste met Week 3 wat die laagste opbrengs toon. Die hoogste opbrengste in die maand word dus verdien in die twee weke periode wat 'n aanvang neem in die laaste week van die maand. Dit verskil van die bevindinge van Jordan \& Jordan (1991) wat aandui dat Weck 2 dic hoogste opbrengs en Week 4 dic laagste opbrengs toon.

Die Eskom 168-effek toon 'n betckenisvolle weekeffek, terwyl dic Poskantoor- en RSA-cffektc diesclfde seisoenale patroon volg, maar nie betekenisvol by dic $5 \%$ betekenispeil is nie. Jordan \& Jordan (1991) se ondersoek dui op 'n betekenisvolle weekeffek ten opsigte van die Dow Jones Composite Bond A verage.

Die beursindekse se hoogste opbrengste is gedurende Week 1. Die laagste opbrengs van die Goudindeks is in Week 2, met die Nywcrheidsindeks en die Algehele Indeks se laagste opbrengs in Week 3. Alhoewel nie betekenisvol nie, volg die Suid-Afrikaanse beursindckse dieselfde patroon as die bevindinge van Jordan \& Jordan (1991), naamlik 'n hoogste opbrengs in Week 1 en 'n laagste opbrengs in Week 3.

Die opbrengste van die beursindekse is baie meer volatiel as dié van die langtermyneffekte. Die daaglikse standaardafwyking van die beursindekse is 199 tot 226 basispunte in die geval van die goudindeks teenoor 49 tot 61 basispunte in die geval van die RSA-effek.

\section{Maandeinde-effek}

Die langtermyneffekte toon positiewe en hoogste opbrengste gedurende die maandeinde dae. Die opbrengs van niemaandeinde dae is negatief. Die patrone is uiters betekenisvol. In teenstelling met die Suid-Afrikaanse mark toon dieselfde effekte in die VSA-markte nie 'n betekenisvolle maandeinde-effek nie (Jordan \& Jordan, 1991).

Die beursindekse toon ook 'n hoogste opbrengs gedurende die maandeinde dae. Die Algehele Indeks toon 'n betekenisvolle maandeinde-effek, met die Goud- en Nywerheidsindeks wat nic betekenisvolle effekte toon nie. Volgens Jordan \& Jordan (1991: 279) is hierdie patroon in die VSA hoogs betekenisvol.

\section{Januarie-effek}

In teenstelling met die bevindinge van Jordan \& Jordan (1991) toon die Suid-Afrikaanse langtermyneffekte nie 'n spesificke Januarie-effek nie. Die Poskantoor-effek het 'n hoogste opbrengs in Desember, die Eskom 168-effek in Julie en die RSA-effek in November. Daar bestaan nie betekenisvolle variasies in dic opbrengste tussen die maande van die jaar nie. Januarie toon 'n negatiewe opbrengs ten opsigte van drie effekte. Die Dow Jones Composite Bond Average vertoon ' $n$ betekenisvolle positiewe opbrengs in Januarie met die ander maande wat deurgaans negatiewe opbrengste of baie klcin positiewe opbrengste toon.

Die hipoteses van gelyke opbrengste oor al die kalendermaande vir die beursindekse kan nie een verwerp word nie. Augustus het die hoogste opbrengs in die geval van beide die Goud- en die Algehele Indekse terwyl Februarie en Desember die hoogste opbrengste toon ten opsigte van die Nywerheidsindcks. Die laagste opbrengste is in Februarie in die geval van die Goudindeks en in Oktober ten opsigte van die Nywerheids- en Algehele Indekse. Die seisoenale patroon stem dus ook nie met die Amerikaanse ondervinding oreen nie. Die afwesigheid van 'n Januarie-effek bevestig die resultate van Bradfield (1990).

\section{Januarie- versus ander nie-maandeinde-effekte}

Die opbrengste van die langtermyneffekte is negatief vir die nie-maandeinde dae. Die opbrengste van die Januarie niemaandeinde dae is deurgaans laer as die res van die jaar se nie-maandeinde dae. Die Eskom 168-en RSA-effek toon 'n betckenisvolle seisoenale effek in sover die opbrengs van 
die Januarie nie-maandeinde dae betekenisvol verskil van die res van die maande se opbrengste op nie-maandeinde dae (groter negatiewe opbrengs). Die resultate is in ooreenstemming met dié van Jordan \& Jordan (1991) se bevindinge, maar die bevindinge verskil in die sin dat die opbrengste van Januaric nie-maandeinde dae in Amerika positief is en die res van die maande se nie-maandeinde dae negatief is.

Die opbrengste van die Januarie nie-maandeinde dae is negatief in die geval van die Goud- en dic Algehele Indeks terwyl die opbrengs van die Nywerheidsindeks ongeveer nul is. Die opbrengste van die res van die maande se nie-maandeinde dae is positief ten opsigte van al drie indekse. Die Algehele Indeks en die Nywerheidsindeks toon betekenisvolle seisoenale patrone in sover die opbrengste van die groeperinge betekenisvol verskil. Bchalwe in hierdie geval, is die resultate in ooreenstemming met dié van Jordan \& Jordan (1991).

\section{Jaareinde- versus maandeinde-effek}

Die opbrengste van die langtermyneffckte gedurende die jaareinde verskil nie betekenisvol van die res van die jaar se maandeinde-dae nie. Al die opbrengste is positief met die opbrengste van die Eskom 168- en RSA-effek se jaareinde opbrengste hoß̈r as die res van die jaar se maandeindes. Die Poskantoor-effek se opbrengs tydens dic jaareinde is egter kleiner as die res. Die Suid-Afrikaanse effekte toon nie 'n betekenisvolle jaareinde-effek nie en verskil dus van dic bevindinge van Jordan \& Jordan (1991: 282).

Die Nywerheids- en Algehele Indeks toon 'n hoogs betekenisvolle seisoenale effek deurdat die opbrengs van die jaareinde dae betekenisvol hoër is as die res van die jaar se maandeinde dae. Die opbrengs van die Goudindeks se jaareinde is ook hoër maar is nie betckenisvol nie. Die SuidAfrikaanse beursindekse volg in hierdie geval dieselfde patroon as in die VSA.

\section{Samevatting en gevolgtrekkings}

Beide die langtermyneffekte en die beursindekse bevat betekenisvolle seisoenale patrone. In tcenstelling met die bevindinge van Jordan \& Jordan (1991) toon die Suid-Afrikaanse langtermyneffekte en die beursindckse oreenkomstige seisoenale patrone in die sin dat waar die een betekenisvol is, die ander ook betekenisvol is. Daar was egter ok uitsonderings soos aangedui in Tabel 1 . In die geval van die effekte was dit hoofsaaklik die Eskom 168- en RSAeffekte wat betekenisvolle seisoenale patrone getoon heh, terwyl patrone in dic Nywerheidsindcks en die Algehele Indeks betekenisvol was.

Die Eskom 168- en RSA-effek het sterk betekenisvolle dag-van-die-week-, maandeinde- en Januarie- versus ander nie-maandeinde-effekte getoon. Die Eskom 168-effek het ook 'n betekenisvolle weekeffek getoon. Die Poskantooreffek het deurgaans dieselfde seisoenale effekte as die ander twee effekte getoon, maar was slegs betekenisvol in die geval van maandeinde-effek.

Die Algehele Indeks het sterk betckenisvolle dag-van-dieweek-, maandeinde-, Januarie- versus ander nie-maandeinde en jaareinde- versus maandeinde-effekte getoon. Die Nywerheidsindeks het sterk betekenisvolle dag-van-dic-week-, Januarie- versus ander-nie-maandeinde- en jaareinde- versus maandeinde-effekte getoon. Die Goudindeks het geen betekenisvolle seisoenale effekte getoon nie.

Daar is dus seisoenale oreenkomste tussen die langtermyneffekte en die beursindekse en dit is eintlik net die jaareinde versus maandeinde seisoenale effek, wat in die geval van die beursindekse betekenisvol was teenoor die effekte waar geen betckenisvolle patrone waargeneem is nie.

In die geheel gesien, toon die langtermyneffekte baie meer prominente seisoenale effekte as die beursindekse.

\section{Summary}

With this article the daily price movements of a number of South African bonds and equity indices are examined in order to determine the existence (or non-existence) of a variety of seasonal patterns and to compare these with results obtained internationally.

Six types of seasonal patterns are investigated, namely the - day-of-the-week effect;

- week-of-the-month effect;

- turn-of-the-month effect;

- January effect;

- January versus other non-tum-of-the-month effect; and

- turn-of-the-year versus tum-of-the-month effect.

The seasonal patterns of three frequently traded bonds namely the Post Office, Eskom 168 and the RSA bonds have been analyzed and were compared with three equity indices namely the Gold Index, Industrial Index and Overall Index, as well as with international results.

Both bond and share indices display significant seasonal patterns. In contrast with the findings of Jordan \& Jordan (1991), the South African bond and share markets display more or less similar seasonal patterns, i.e. when bonds show a significant pattern, equities also show a significant pattern. In the bond market the Eskom 168 and the RSA bonds display significant seasonal patterns while the Industrial and Overall Share Indices display significant seasonal patterns. The Eskom 168 and RSA bonds display significant day-ofthe-week, turn-of-the-month and January versus other nonturn-of-the-month effects. The Post Office bonds display similar patterns, but are only significant in the case of the turn-of-the-month effect. The Overall Share Index displays significant day-of-the-week, turn-of-the-month, January versus other non-tum-of-the-month and tum-of-the-year versus turn-of-the-month effects, while the Industrial Index displays significant day-of-the-week, January versus other non-turn-of-the month and turn-of-the-year versus turn-ofthe-month effects. The Gold Index does not display any significant seasonal patterns.

Seasonal similarities exist between the bond and the share markets. The results show that when bonds display a significant seasonal pattem, the share indices also display significant effects. It is only the tum-of-the-year versus the turn-of-the-month effect which differs between the two groupings. In this regard the South African market thus differs from documented findings. 


\section{Verwysings}

Ariel, R.A. 1987. 'A monthly effect in stock returns', Journal of Financial Economics, Vol. 18: 161-174.

Bhana, N. 1985. 'The Monday effect on the Johannesburg Stock Exchange', Suid-Afrikaanse Tydskrif vir Bedryfsleiding. Vol. 16: 7-11.

Bradfield, D.J. 1990. 'A note on the seasonality of stock returns on the Johannesburg Stock Exchange', Suid Afrikaanse Tydskrif vir Bedryfsleiding, Vol. 21: 7-9.

Gibbons, M.R. \& Hess, P. 1981. 'Day of the week and asset returns', Journal of Business, Vol. 54: 579-596.

Hattingh. F.S. 1992. Seisoenale patrone in die Suid-Afrikaanse kapitaalmark. Ongepubliseerde M.B.A.-werkstuk. Bellville: Universiteit van Stellenbosch Bestuurskool.

Jaffe, J.F. \& Westerfield, R.W. 1985. 'The week-end effect in common stock returns: the international evidence', Journal of Finance, Vol. 40: 433-454.
Jordan, S.D. \& Jordan, B.D. 1991. 'Seasonality in daily bond returns', Journal of Financial and Quantitative Analysis, Vol. 26: 269-285.

Keim, D.B. 1983. 'Size-related anomalies and stock return seasonality: further empirical evidence', Journal of Financial Economics, Vol. 12: 13-32.

Keim, D.B. 1986. 'The CAPM and equity return regularities', Financial Analysts Journal, Mei-Junie: 19-34.

Lakonishok, J. \& Smid, S. 1984. 'Volume and tum-of-the-year behavior', Journal of Financial Economics, Vol. 13: 435-455.

Pettengill, G.N. \& Jordan, B.D. 1988. 'A comprehensive examination of volume effects and seasonality in daily security returns', Journal of Financial Research, Vol. 11: 57-70.

Rogalski, R.J. 1984. 'New findings regarding day-of-the-week returns over trading and non-trading periods: a note', Journal of Finance, Vol. 39: 1603-1614. 